\title{
Fair or Foul: Time for Standard Protocols for Potential Application of Adipose-Derived Stem Cells?
}

\author{
Yue Zhao, Christopher Betzler, Felix Popp and Christiane Bruns* \\ Department of General, Visceral und Vascular Surgery, Otto-von-Guericke University, Germany
}

\begin{abstract}
Adipose tissue derived stem cells (ASC) has currently been highly attracted as a new source for regenerative medicine as well as promising avenue of investigation for the delivery of adjuvant therapies in various disease. A criticized standard protocol of generating purified good quality and quantity of ASCs is emergent in need.
\end{abstract}

Keywords: Adipose tissue; Stem cells; Characterization; Clinical application

\section{To the Editor}

Kakudo et al. [1] recently summarized the potential application of adipose-derived stem cells in regenerative medicine. In their article, the authors compared the methods of ASCs isolation, characterization, and also described the transcriptome and proteome of ASCs as well as different clinical application. They emphasized the subcutaneous adipose tissue served as an easy and safe source for clinical application [2]. The automatic adipose-derived stem cells isolation system might be suitable for fresh ASCs application by using Celution ${ }^{\circledR}$ 800/CRS (Cytori Therapeutics, San Diego, CA) [3] and Tissue Genesis Icellator Cell Isolation System ${ }^{\circ}$ (Tissue Genesis, Inc., Honolulu, Hawaii). Bianchi F et al also reported a new nonenzymatic method, named as 'Lipogems', providing a nonexpanded, ready-to-use fat product and even being able to stored frozen without losing the ability to release highly functional and viable hMSCs after thawing as compared to commonly used lipoaspirate-based method [4].

However, for the manual separation methods, a standard protocol either for human or experimental model animals is still need to be well developed. There is different information about the types of the fat resource, animal species, cell processing steps and expanding conditions, in particular for adherent ASCs protocol, which mainly depends on the lab background and research purpose.

We agreed that there are various opinions about cell surface markers of ASCs without a consensus yet. Changes in ASCs markers due to the culture conditions and number of passages have been pointed out as causes of this inconsistency [1,5]. Maikel Varma et al. showed that freshly isolated ASCs slightly differed in immunophenotype from cultured ASCs, freshly isolated ASCs displaying highly positive for CD34, and positive for CD117 and HLA-DR [6]. In this journal, a report by Gowda and his colleagues evaluated optimum culture conditions for efficient large-scale stem cell expansion [5]. They compared different medium combinations and seeding densities and showed that 25:75 DMEM-KO/a-MEM at a seeding density of $5000 \mathrm{cells} / \mathrm{cm}^{2}$ generated significantly higher cell yield than the other medium combinations, while preserving their stem cell characteristics and differentiation potential. This information provides good manufacturing practice (GMP) guidance for standardizing ASCs production. The similar study was also reported by Pawitan et al to show that different media selection caused different quality of ASCs [7].

Recently a new, reliable method for enrichment of white adipose tissue (WAT) MSCs based on lineage-negative (Lin -) cell population selection was reported, with even greater amounts of MSC markers than stromal-vascular fraction (SVF) cells which relies on the adhesiveness of the culture and particular passages [8]. This protocol may also help to generate a standard protocol for a fast ASCs enrichment.

The usage of ASCs is usually ranged from passage 4-6. The shortage of cells number and replicative senescence in limited lifespan, known as the "Hayflick limit" in vitro, limits their further clinical application. Martin A. Vidal and colleagues evaluated the senescence in MSCs from fat tissue with data of population doublings, b-galactosidase staining, telomere length detection as well as Sox 2 expression (essential for cellular pluripotency and self-renewal) [9]. Replicative senescence of MSC preparations was confirmed as a continuous process starting from the first passage onwards [10]. Wang et al. transfected with human telomerase reverse transcriptase (hTERT) gene by the lentiviral vector to prolong the lifespan of stem cells and even immortalize them [11]. Recently a group also demonstrated that hASCs, upon immortalization, maintain a strong capacity to secrete potent angiogenic molecules and can be employed in in vivo cell-tracking experiments, expanding their potential use in laboratory practice [12].

As the development of ASCs' study from the bench to the

\begin{tabular}{|c|c|c|}
\hline Procedure & $\begin{array}{l}\text { GMP associated information for ASCs } \\
\text { production }\end{array}$ & Reference \\
\hline Collection & $\begin{array}{l}\text { fat pad, liposuction aspiration or Lipogems } \\
\text { product }\end{array}$ & {$[1,3,4]$} \\
\hline Isolation & Collagenase digestion vs. nonenzymatic method & {$[1,4,5]$} \\
\hline Purification & Adherent culture vs. lineage-negative sorting & {$[1,3,5,8]$} \\
\hline Expansion & Freshly isolated cells vs. cultured cells & [8-11] \\
\hline Characterization & $\begin{array}{l}\text { Immunophenotype, Differentiation capacity, } \\
\text { Colony formation, Transcriptome and Proteome }\end{array}$ & [3-8] \\
\hline Clinical application & $\begin{array}{l}\text { Diabetes, ischemic injury, liver injury, kidney } \\
\text { injury, cardiac repair, retinopathy, inflammatory } \\
\text { diseases, transplant tolerance, erectile } \\
\text { dysfunction, nerve repair, anti-cancer therapy }\end{array}$ & {$[1,2,13]$} \\
\hline
\end{tabular}

Table 1: Summary of safety, reproducibility and quality widespread clinical use of adipose-derived stem cells.

*Corresponding author: Professor Christiane Bruns, Department of General, Visceral und Vascular Surgery, Otto-von-Guericke University, Leipziger strasse 44, Magdeburg, 39120, Germany, Tel: +49 0391 6701; E-mail: christiane.bruns@med.ovgu.de

Received June 20, 2014; Accepted July 26, 2014; Published July 28, 2014

Citation: Zhao Y, Betzler C, Popp F, Bruns C (2014) Fair or Foul: Time for Standard Protocols for Potential Application of Adipose-Derived Stem Cells? J Stem Cell Res Ther 4: 220. doi:10.4172/2157-7633.1000220

Copyright: (c) 2014 Zhao Y, et al. This is an open-access article distributed under the terms of the Creative Commons Attribution License, which permits unrestricted use, distribution, and reproduction in any medium, provided the original author and source are credited. 
Citation: Zhao Y, Betzler C, Popp F, Bruns C (2014) Fair or Foul: Time for Standard Protocols for Potential Application of Adipose-Derived Stem Cells? J Stem Cell Res Ther 4: 220. doi:10.4172/2157-7633.1000220

Page 2 of 2

clinic, focus is switching from characterization to develop largescale manufacturing processes with relevant quality controls for the production of ASCs in accordance with evaluable and comparable manufacturing practices [13]. Therefore, standard criteria is emergent in need for a safety, reproducibility and quality widespread clinical use of adipose-derived stem cells (Table 1).

\section{References}

1. Kakudo N, Morimoto N, Ogawa T, Kusumoto K (2014) Potential of AdiposeDerived Stem Cells for Regeneration Medicine: Clinical Application and Usefulness of Fat Grafting. J Stem Cell Res Ther 4: 204.

2. Ishikawa T, Banas A, Hagiwara K, Iwaguro H, Ochiya T (2010) Stem cells for hepatic regeneration: the role of adipose tissue derived mesenchymal stem cells. Curr Stem Cell Res Ther 5: 182-189. [PubMed]

3. Lin K, Matsubara Y, Masuda Y, Togashi K, Ohno T, et al. (2008) Characterization of adipose tissue-derived cells isolated with the Celution system. Cytotherapy 10: 417-426. [PubMed]

4. Bianchi F, Maioli M, Leonardi E, Olivi E, Pasquinelli G, et al. (2013) A new nonenzymatic method and device to obtain a fat tissue derivative highly enriched in pericyte-like elements by mild mechanical forces from human lipoaspirates. Cell Transplant 22: 2063-2077.

5. Gowda S, Hari A, Chougule B, Reddy MK, Chandanan A, et al. (2013) Production of Good Manufacturing Practice Grade Equine Adipose-derived Mesenchymal Stem Cells for Therapeutic Use. J Stem Cell Res Ther 3: 154.
6. Varma MJ, Breuls RG, Schouten TE, Jurgens WJ, Bontkes HJ, et al. (2007) Phenotypical and functional characterization of freshly isolated adipose tissuederived stem cells. Stem Cells Dev 16: 91-104. [PubMed]

7. Pawitan JA, Des Suryani DW, Damayanti L, Purwoko RY, Liem IK (2013) Flow Cytometry Analysis Of Adipose Tissue-Derived Stem Cells That Were Cultured In Various Media. International Journal of PharmTech Research 5: 1301-1306.

8. Qin Y, Zhou P, Zhou C, Li J, Gao WQ (2014) The adipose-derived lineagenegative cells are enriched mesenchymal stem cells and promote limb ischemia recovery in mice. Stem Cells Dev 23: 363-371.

9. Vidal MA, Walker NJ, Napoli E, Borjesson DL (2012) Evaluation of senescence in mesenchymal stem cells isolated from equine bone marrow, adipose tissue, and umbilical cord tissue. Stem Cells Dev 21: 273-283. [PubMed]

10. Wagner W, Horn P, Castoldi M, Diehlmann A, Bork S, et al. (2008) Replicative senescence of mesenchymal stem cells: a continuous and organized process. PLoS One 3: e2213. [PubMed]

11. Wang L, Song K, Qu X, Wang H, Zhu H, et al. (2013) hTERT Gene Immortalized Human Adipose-Derived Stem Cells and its Multiple Differentiations: a Preliminary Investigation. Appl Biochem Biotechnol 169: 1546-1556. [PubMed]

12. Balducci L, Blasi A, Saldarelli M, Soleti A, Pessinaet A, et al. (2014) Immortalization of human adipose-derived stromal cells: production of cel lines with high growth rate, mesenchymal marker expression and capability to secrete high levels of angiogenic factors. Stem Cell Res Ther 5: 63. [PubMed]

13. Cawthorn WP, Scheller EL, MacDougald OA (2012) Adipose tissue stem cells: the great WAT hope. Trends Endocrinol Metab 23: 270-277. [PubMed] 